Accounting, Auditing \& Accountability Journal

emerald

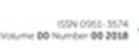

Accounting, Auditing \&

Accountability Journal

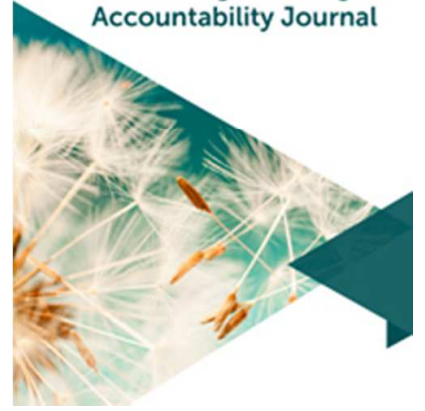

Toward a Political Economy of Corporate Governance Change and Stability in Family Business Groups: A Morphogenetic Approach

\begin{tabular}{|r|l|}
\hline Journal: & Accounting, Auditing \& Accountability Journal \\
\hline Manuscript ID & AAAJ-01-2017-2833.R2 \\
\hline Manuscript Type: & Research Paper \\
\hline Keywords: & $\begin{array}{l}\text { Corporate Governance, Family Business Groups, Political Economy, Critical } \\
\text { Realism, Morphogenetic Approach, Bangladesh }\end{array}$ \\
\hline \multicolumn{2}{|l}{} \\
\hline
\end{tabular}

$$
\begin{gathered}
\text { SCHOLARONE } \\
\text { Manuscripts }
\end{gathered}
$$




\title{
Toward a Political Economy of Corporate Governance Change and Stability in Family Business Groups: A Morphogenetic Approach
}

\begin{abstract}
Purpose - This paper aims to elaborate a political economy of corporate governance (CG) change and stability in family business groups (BGs) and assist in explaining why certain CG reforms fail in one context but work in others.

Design/methodology/approach - Three BGs in Bangladesh are studied. A mixture of data sources is used, namely interviews, observations of practices, historical documentation, company reports, and research papers and theses. The results are analysed by applying Archer's morphogenetic approach, focusing on both macro and micro processes of change.

Findings - A newly-adopted CG framework, which created incentives and pressures for family directors to act in the best interests of general shareholders, did not seem to alter apparently simple but complex internal structural set-ups. Thus, regulatory efforts to empower general shareholders did not produce the expected results. Following Archer's morphogenetic approach, we identify key structural conditioning or emergent properties and agential strategies to explain why and how BGs opted for symbolic compliance and achieved lax regulation and enforcement.

Originality/value - The morphogenetic approach aids in developing a political economy of CG change and stability and provides a nuanced explanation of CG practices. This is illustrated through an exploration of CG change initiatives in Bangladeshi BGs.

Research implications - The paper opens up a new methodological and theoretical space for future CG research, especially by applying a meta-theoretical guideline such as the morphogenetic approach, for nuanced explanation and a more inclusive understanding of CG practices, reform and change in different organisational and institutional settings.
\end{abstract}

Keywords Corporate governance, Family business groups, Political economy, Critical realism, Morphogenetic approach, Bangladesh

Paper type Research paper 


\section{Introduction}

This paper contributes to the corporate governance $(\mathrm{CG})$ debate around vicious cycles of reform and scandal in a range of national contexts (Yonekura et al., 2012; Ahrens et al., 2011). Most previous studies have tended to address this debate by predicting how particular CG inputs may lead to certain outcomes, but have left practice in a "black box" (Brennan and Solomon, 2008). CG recommendations are often based on such predictions, taking for granted that "change" in practice will have far-reaching benefits. Researchers have called for direct engagement with CG practices in various contexts to gain a broader understanding of $\mathrm{CG}$ reforms, scandals and practices (Aguilera and Crespí-Cladera, 2016; Brennan and Kirwan, 2015).

Some studies have examined CG practices by focusing on diverse institutional contexts leading to variations in CG practices (Yonekura et al., 2012; Peng and Jiang, 2010). From this perspective, CG is explained as an embedded practice shaped by deep-seated institutions. However, its exclusive focus on macro-level institutions arguably reduces the scope for organisational-level micro-processes. In contrast, other studies give prominence to the role of key actors in the construction of meaning, and the effectiveness of different CG mechanisms and resulting actions (Cullen and Brennan, 2017; Tremblay and Gendron, 2011). Salient to their explanation is recognition of the agency of actors with varying interests, information asymmetries and power that appear to play a crucial role in shaping both reform initiatives and resultant practice (Brennan et al., 2016; Joseph et al., 2014). Nevertheless, agency-based explanations tend to neglect institutional conditions that may constrain and/or enable actors' constructions, behaviour and actions. Consequently, a fundamental question that has not been satisfactorily addressed is why certain CG reforms drive changes to practices in one context but not in others.

We seek to address this research question by exploring the multiplicity of interests in the distinct ownership and control setting of family business groups (BG), a common business ownership pattern mainly in companies located outside the Anglo-American sphere (Holderness, 2009; La Porta et al., 1999). This paper aims to develop a political economy of CG change and stability and assist in explaining why certain CG reforms fail in one context but appear to work in others. We endeavour to explicate the political economy of change and stability in CG practices in an organisational setting, through direct engagement with the institutional context and key actors. Our qualitative inquiry centres around the underlying structural (material and cultural) conditions necessary to sustain certain types of CG practice, and how facilitation and/or constraint of agencies by those conditions ultimately shape CG practices.

Our reasons for focusing on family BGs in an emerging economy are twofold. First, such businesses, irrespective of their institutional settings, present unique governance problems. This is evident in recent research that argues that agency conflict, ownership and control interests are likely to differ in nature in family BG settings (Aguilera and Crespí-Cladera, 2012). However, theoretical and empirical development has paid relatively little attention to the $\mathrm{CG}$ practices of public limited companies (PLCs) in family BG settings (Colli and Colpan, 2016; Jansson and Larsson-Olaison, 2015).

Second, global market integration is creating pressure for the proliferation of similar, mainly Anglo-American, CG models around the world (Cuomo et al., 2016). This poses distinct CG challenges to companies in emerging economies in general, owing partly to their institutional settings and traditions, but particularly to family BGs (Lien et al., 2015; Yonekura et al., 2012). Nevertheless, broader theorisation of change and/or stability in CG practices in family BGs remains neglected (Aguilera and Crespí-Cladera, 2016; Uddin and Choudhury, 2008). 
The paper proceeds as follows. Section 2 reviews the contemporary CG literature and further justifies the need for this research. Section 3 explains Archer's morphogenetic approach and its relevance to this research. Section 4 outlines the research design, and Section 5 presents the empirical findings, applying a morphogenetic cycle illustrated with previous studies. Section 6 considers a practical social theory of CG change and stability following the morphogenetic tradition. The paper concludes by highlighting the contributions of this research.

\section{Corporate governance reforms and change in family business groups}

The ongoing CG reform agenda, rooted in shareholder value, agency theory and rational choice models, has led accounting and finance researchers to study numerous CG mechanisms to address conflicting interests between owners and managers (type I agency conflict) and within owner groups (type II agency conflict; see Brennan and Solomon, 2008 for a detailed review). Nevertheless, critical accounting scholars have questioned the supremacy of shareholder value logic and its ideological roots (Sikka and Stittle, 2017; Merino et al., 2010; Stein, 2008; Marnet, 2007). This is lucidly observed by Pesqueux (2005, p. 798): "Mixed with the illusion of accounting systems built to inform shareholders seen as 'rational', corporate governance produces the mask of dominant interests by focusing the attention on the importance of a so called 'conflict of interests' between shareholders and managers." Researchers have also questioned the fundamentals of Anglo-American models in various institutional and organisational settings (see Yonekura et al., 2012; Merino et al., 2010; Siddiqui, 2010). Emerging from these studies is the notion that reforms often fail in their aim to institutionalise certain CG practices (see Yonekura et al., 2012).

In parallel, a growing body of CG research has paid attention to the dynamics of agential interests, consent and resistance (Rose et al., 2013; Cohen et al., 2013; Tremblay and Gendron, 2011), construction of meaning (Gendron and Bédard, 2006), accountability processes (Brennan et al., 2016; Shaoul et al., 2012), control and power relations (Cullen and Brennan, 2017; Parker, 2008), and internal processes, institutions, values and norms (Nicholson et al., 2017; Hermanson et al., 2012; Beasley et al., 2009; Turley and Zaman, 2007) implicated in organisational-level CG practices in different contextual settings. In a bid to explain the gaps between reforms and change, recent studies expose an apparent disparity in stakeholder expectations and, more importantly, a gap in our current understanding of complex, real-world, contextual/practical reality (Cullen and Brennan, in 2017; Brennan and Kirwan, 2015; Parker, 2008), and the paradoxes (Brennan et al., 2016) and lived experiences of CG (Ahrens and Khalifa, 2013). These recent developments warrant a greater need to glean insights into $C G$ practices in different contexts.

Existing research seems weak in addressing debate on CG reform, practice and change with respect to answering why reforms often fail to achieve their aim, in terms of instituting material changes in CG practices. We would argue that this weakness is due mainly to a disjointed focus on institutional contexts and agency in existing explanatory accounts (McNulty et al., 2013). For instance, institutional studies arguably pay relatively more attention to macro institutions in the constitution of CG practices, and hence a legacy of micro-myopia appears to taint the field. In line with Ahrens and Khalifa (2013), we believe that this legacy has, to some extent, contributed to limiting the potential of institution-based explanations to transcend the "disconnect between CG research and practice" (Brennan and Kirwan, 2015). We seek to address this weakness by incorporating the interplay of institutional contexts and agency in our explanatory account, which embraces a political economic perspective. 
CG studies in accounting are diverse in terms of their coverage of a variety of sectors, including publicly-listed companies (Hermanson et al., 2012; Cohen et al., 2013; Beasley et al., 2009), non-profit entities (Parker, 2008), investment funds (Cullen and Brennan, 2017) and public-sector and public-private partnerships (Subramaniam et al., 2013; Shaoul et al., 2012). Nonetheless, family BG-affiliated, publicly-listed companies, prominent in emerging economies and elsewhere (outside the UK and USA), remain generally under-researched and theorised. The literature commonly treats family BGs as a convenient context for testing theory (Siebels and $\mathrm{Zu}$ Knyphausen-Aufsess, 2012), rather than as a subject of unique theoretical interest.

In general, it is held that family relationships make agency conflicts more difficult to resolve (see Young et al., 2008; Schulze et al., 2003), particularly when individuals hold multiple positions. Rather than focusing on the typical debate about family control and agency conflicts, we engage directly in delimiting the material and cultural conditions under which family control is sustained and implicated in CG practices through agential actions. Our position is inspired by recent research revealing that family control operates along different dimensions, depending on the power relations of actors in a particular context (Bettinelli, 2011; Li and Filer, 2007). Family owners (also referred to as family directors) in BGs tend to nurture asymmetrical power and control interests more than other owner groups such as dispersed shareholders, institutional shareholders and the state (Aguilera and Crespí-Cladera, 2012). Non-family managers also play a critical role in embedding the control interests of powerful family directors, especially in emerging economies (Li and Filer, 2007).

Researchers argue that, even in Anglo-American institutional settings, powerful corporate elites manipulate CG structures and recommendations, signalling conformity while causing minimal disruption to their balance of power (Joseph et al., 2014; Westphal and Graebner, 2010). Joseph et al. (2014, p. 1835) find that powerful CEOs in "CEO-only" board structures (where the CEO is the only insider on the board) in the USA promote their own interests by taking advantage of an information brokerage position on the board and eliminating potential internal contestants. In the same spirit, Brennan and Kirwan (2015) examine ritualistic ceremonial behaviours and symbolic endeavours vis-à-vis substantive engagement of audit committee (AC) practitioners in oversight roles.

The above literature suggests that a grounded understanding of CG practices demands a fresh examination of the actions of family actors in the acquisition and maintenance of power relations and control interests in the upper echelons of BGs. This would offer greater visibility of the social relations and power dynamics surrounding family control interests and, more importantly, of agential interactions with the underlying material and cultural conditions shaping CG practices in BG-affiliated PLCs. This visibility is particularly important, given that CG reforms and practices are increasingly viewed as contested terrains for the materialisation of divergent material and cultural interests, triggering political economic considerations (Jansson et al., 2016).

We offer a meta-theoretical model, taking a morphogenetic approach to provide a platform to explain CG change and stability. We build on the seminal writings of contemporary British sociologist, Margaret S. Archer (1995), according to whom social reality depends on human doings and their desired or undesired consequences. This approach is operationalised through an empirical study of family BGs in Bangladesh, a country characterised by a weak capital market, lack of institutional development, corruption, family kleptocracy, weak state power and family-business nexus (Uddin et al., 2016; Sobhan, 2016). Our privileged access and 
insights make a significant contribution to the relatively under-explored field of CG practice and praxis.

\section{Theoretical approaches and morphogenetic approach to CG}

Our adoption of a morphogenetic approach is consistent with an urgent call by critical scholars to move beyond agency theory (Parker and Northcott, 2016; Guthrie and Parker, 2012; Gendron, 2009). A battery of theoretical perspectives ${ }^{1}$ has previously been used to explain various CG mechanisms and processes (Christopher, 2010). Fully embracing the spirit of the emancipatory rationale of interdisciplinarity in accounting research (Gallhofer and Haslam, 2017), we draw on sociological theorisation to address the political economy of CG practices, change and stability.

The main thrust of the morphogenetic approach is to understand how the causal power of "structural properties" is mediated through "people" (agency). From a morphogenetic perspective, the "morpho" element acknowledges the structural (material or cultural) properties of society, and the "genetic" part recognises that society takes its shape from, and is formed by, agents, originating from the intended and unintended consequences of their activities. Thus, in advancing a causal and practical explanation of social practice (in our case CG practices), Archer (1995) makes a case for focusing on structural conditioning (arising out of both material and cultural conditions) and agential actions. ${ }^{2}$ To conceive material conditions, Archer directs researchers to focus on relationships between objects, positions and institutions. For instance, relationships between the state and regulators, and relationships between family directors and managers establish certain dispositions or vested interests for each actor's or institution's actions and behaviour. Similarly, to conceive cultural conditions, Archer recommends focusing on relationships between ideas, beliefs and concepts. For instance, family value versus shareholder value logics are two sets of ideas that may strongly influence actors to take an enterprise in a particular direction.

Structural conditioning, described above as a set of relationships, is also understood in terms of relations of necessary/internal or contingent/external interdependencies. A necessary internal relation means a relationship between two or more positions, objects and ideas when none can exist without the other. For example, in a public limited company, the positions of shareholders and directors are internally linked, as the position of director is meaningless in the absence of shareholders, and vice versa. An external contingent relation is a relationship between two or more positions, objects or ideas where one is able to exist without the other. For example, relations between two institutions, such as the state and donor agencies, are contingently linked, as either may exist without the other. These relationships pre-exist and determine the position confronted by the present generation of actors.

The interplay between structure and agency is captured sequentially in the morphogenetic approach, first by examining how structural conditioning affects social interactions, and second by considering how these interactions, in turn, lead to structural elaborations, or outcomes, at time T3-T4. Actors' social interactions take place in the context of structural conditioning. Actors reflect on a situation subjectively in connection with their personal life projects. ${ }^{3}$ The structural elaboration or outcome of agential actions and interactions may be either morphogenesis (a change in structure/culture) or morphostasis (an absence of change in structure/culture).

As Archer acknowledges, the morphogenetic approach is intended as a starting point for researchers to develop an appropriate theory, or what Archer $(1995$, p. 328) calls practical social theory (PST), of social change and stability. According to Archer (2013, p. 9), applying this as a 
meta-theoretical guideline in the field of CG change and stability allows us to view organisations/BGs as an array of internally linked (shareholders-directors-management) and externally linked (BGs-regulatory bodies) positions and relationships. These relationships and positions have emergent power to dispose actors such as shareholders and managers to act in one way rather than another. Shareholders and managers are vested interest groups, and hence actors, and by virtue of occupying specific positions in the structure, they necessarily confront these dispositions; nevertheless, they act based on their reflections on structural influences in light of their life projects.

\section{[Insert Figure 1]}

Figure 1 illustrates structural conditions and how they dispose actors to change the system or preserve the status quo. At $\mathrm{T} 1$, the first step is to identify material and cultural conditioning, such as relations between positions, institutions and ideas. These conditioning influences have the power to constrain or enable agential actions. Put simply, those in privileged positions, in terms of their access to resources, will have strong incentives to reproduce the same structural conditions, but this is not predetermined. Archer (1995) identifies four possibilities of distinct situational logics of actors: protection, compromise, opportunism and elimination (see Figure 1). These logics are conditioned or shaped by the nature of dominant agential vested interests and life projects, in terms of the extent of their interdependence (internal or contingent relationships) and logical linkages (compatible or contradictory) in both the material and cultural spheres. These potential scenarios provide an understanding of the actions of the various groups of actors within the organisation at $\mathrm{T} 2$.

In the second phase (T2) of the morphogenetic cycle - agential interactions with structures - situational logics may lead to four possible agential actions: accept, reject, evade or manipulate. During this interaction phase, different actors confronting the same situational logic may reflect on it quite differently in light of their life projects, and their actions may consequently vary. For instance, owing to personal religious orientations, family directors may decide not to expand the business by applying the most cost-effective mode of financing, such as debt capital. In essence, actors may conform to the conditioned action, or diverge and accept the cost, or may even display an inventive capacity and circumvent the constraints posed by the structure (Archer, 1995). Therefore, Archer (2003, p. 137) proposes that neither involuntary acquisition of vested interests in the maintenance of privileges nor transformation of deprivation will necessarily automatically be translated into the corresponding action.

The ultimate desired or undesired outcome of social interactions is a structural elaboration at time T3 leading to morphogenesis (change) or morphostasis (no change). Thus, the morphogenetic cycle, with its historical account of the elaboration of present structures and culture, tends to reveal interactions between human actors and past structures. The morphogenetic approach looks at this process over time, dealing with endless sequences and cycles of structural conditioning $\rightarrow$ social interaction $\rightarrow$ structural elaboration.

We illustrate this cycle by focusing on three key features of the meta-theoretical framework: (i) relationships between positions (family directors, shareholders, managers), institutions (family, regulatory bodies, donor agencies) and ideas (family logics), elaborating their interdependence (internal or contingent relationships) and logical linkages (compatible or contradictory), i.e. structural conditioning; (ii) situational logics and actions of key actors, i.e. social interactions; and (iii) outcomes, i.e. structural elaborations. This will enable us to 
understand CG changes (if any). To this end, a practical social theoretical model of CG change and stability emerges, illustrated by the findings (see Figure 2).

\section{Research methodology}

Family dominance in listed PLCs and ongoing CG reforms in Bangladesh (ADB, 2016; World Bank, 2009), mainly under pressure from its development partners, make it an interesting empirical setting in which to conduct a study. This paper focuses on the three largest family BGs, in terms of both value of assets and number of publicly-listed companies. The parent/holding companies of the three groups studied in this paper are private limited companies owned by the founders' families. The ownership stake of the founder families is intensified, both directly by their share ownership, and also indirectly through their parent companies' investment in the individual companies held by the BG, some of which are listed on the stock exchange. The three BGs studied have eleven PLCs listed on the Dhaka Stock Exchange.

Methodologically, we followed a retroductive mode of inference by asking a typical critical realist question: what must be there because of which certain types of CG practice exist? We first attempted to understand empirical CG practices at time T3 (present/end of the period under investigation) from in-depth interviews with actors, and then regressed these practices back to agential actions and interpretations. In the BG setting, with pervasive control in the hands of family directors, it was particularly important to understand their agential concerns in relation to $\mathrm{CG}$ practices. We corroborated our interview findings with archive materials, including interviews with and biographies of BG founders available in electronic and print media, and interrogated documents formulated for entirely different purposes, since the actors could not be consulted directly on all matters (Mutch, 2007).

$\mathrm{CG}$ practices are subject to internal norms as well as external rules and regulations from regulators. Hence, it was important to trace agential actions at time T2 (during the period under investigation) back to these rules and norms. The extensive documentary evidence consisted of both published documents, such as annual reports, regulatory notifications, reports available on the companies' websites and various legislation such as the Companies Act 1994, and unpublished internal documents made available for this investigation, such as agendas and minutes of important meetings, codes of conduct/ethics, terms of reference and job descriptions for senior managers, and memoranda and articles of association. These, in corroboration with the interview findings, were useful for this purpose. Before interviewing actors, we tried to gather as much information as possible from the published annual reports of the various PLCs held by each BG. This helped us to appreciate the nature of the family involvement, ownership stakes, interlocking positions and status of members in the concerned PLC before approaching the actors for interview.

In total, 32 interviews (including two group interviews) were conducted in two rounds, from February to August 2013 and from June to August 2016, with nine regulators, five family directors, six independent directors, eleven senior non-family managers and two groups of general shareholders. The first round took place at an early stage (within a year of the mandatory compliance requirement), when the companies investigated were still in the process of forming their ACs, and the AC chairs had attended only one or two AC meetings. We therefore opted for a second round to generate more data, particularly on AC practices. All except three interviews lasted between 60 and 120 minutes, with an average duration of 30 to 40 minutes. Field notes were taken during the interviews, which were conducted mainly in Bangla. We later transcribed the interviews into English. 
We were privileged to be able to interview a number of family directors who held multiple positions within the BGs. More importantly, they shared with us their personal and family attachments with the business, as well as confidential internal documents such as terms of reference and codes of conduct for family members only. Although all of our interviews were semi-structured with open-ended questions, we continuously revised the questions prior to approaching the next interviewee. Some interviewees, on condition of strict confidentiality and anonymity, provided us with access to unpublished company documents. We updated our interview guide in light of that data. We scheduled the interviews chronologically, ensuring that family directors were the last to be interviewed. All interviewees were given the option of reviewing our understanding of and excerpts from their comments. Only one requested this. In addition to the interviews, the first author attended six annual general meetings (AGMs) to observe shareholders' interactions with the family directors and independent directors.

We also drew on the cultural and political history literature and conducted an extensive documentary survey of published reports by organisations such as the World Bank, ADB and other donors, research papers by think tanks and civil society institutions, and unpublished reports from various bodies, such as probe reports on the stock market collapse. Useful interviews were also conducted with officials from regulatory bodies and donor agencies, and with members of civil society organisations. Thus, understanding the empirical CG practices and locating them in the material and cultural conditions at time T1 allowed us to unravel a "deep" extra-experiential level of reality (Sayer, 1992).

We conducted thematic analysis of the interviews and documentary and archival sources using Framework as a data management tool. ${ }^{4}$ While the themes were largely grounded in the dataset, production of exploratory accounts required us to move to a more interpretive stage, developing more abstract analytical constructs based on theoretical guidelines such as structural conditioning (T1), social interactions (T2) and structural elaborations (T3). This allowed us to devise a theoretically-informed story of CG practices and illuminate the causal mechanisms at work at the level of the "real" by deploying the logic of retroduction (O'Mahoney and Vincent, 2014; Sayer, 1992).

\section{Results}

\subsection{Structural conditions and CG practices at $T 1$}

The morphogenetic approach requires CG practices to be situated within the realist context of time and space. We did this by tracing back from the present $C G$ guidelines and practices (at time T3) to the underlying material and cultural structural conditions (at time T1) that had shaped them. We did this by situating the BGs within the cultural and political history of Bangladesh. We identified three key structural conditioning or emergent properties: (i) the emergence of BGs and family logics/values; (ii) relations between positions (family directors, general shareholders, and managerial and family control); and (iii) relations between institutions (donor agencies and the state). These are each addressed in turn in the next sub-sections. The key structural conditioning properties set the context for new CG guidelines.

\subsubsection{Emergence of business groups and family logics}

There was virtually no ethnic Bengali capitalist class in the colonial history of Bangladesh. Following the colonial regime of the "British Indian Empire" (1876-1947), East Bengal (now Bangladesh) became part of the newly-formed Pakistan state, known as East Pakistan, in 1947. 
The partition of British India severely disrupted the former colonial economic system that had preserved East Bengal as an agrarian economy with an exceptionally low industrial base. The initial nucleus of the entrepreneurial class emerged from some migrant non-Bengali capitalist and West Pakistani groups, strongly supported by the new Pakistani state (Papanek, 1967). As a result, by 1968, a mere 22 West Pakistani families controlled 66 per cent of the country's total industrial capital, 70 per cent of insurance, and 80 per cent of banking (Business Recorder [Karachi], 25 April 1968), leaving only few small and medium-sized enterprises to the Bengali capitalist class (Khan, 1999, p. 16).

Following independence in 1971, the flight of the West Pakistani capitalist class from Bangladesh benefited the few wealthy Bengali families who owned small to medium-sized enterprises (Sobhan, 1980). The strong presence of familial values drove the financing of these enterprises through capital and loans from informal channels such as family, friends and other social ties, and they were traditionally operated through close-knit, family-dominated management structures (Papanek, 1972). This was perhaps intensified by a lack of available capital from securities markets and banks (Solaiman, 2006; Sobhan, 1980). Although all businesses were nationalised in the immediate aftermath of independence, that situation did not last long. From 1975 onwards, subsequent governments accelerated the privatisation programmes that eventually led to the emergence of new family-based business elites (Kochanek, 1996). Over 400 privatisations have taken place in Bangladesh since 1976, and most privatised companies "are now closely-held by a single owner or family" (World Bank, 2009, p. 2). Over time, the family BGs expanded and diversified their businesses through the direct and indirect patronage of political elites (Uddin et al., 2016; Muttakin et al., 2015). This was further strengthened by family and kinship ties deeply rooted in Bangladeshi cultural and political history, as well as the weak state (Uddin, 2009; Sobhan, 2002).

Nevertheless, the appetite for growth pushed many first-generation BGs to resort to stateowned banks for financing. Their reluctance to go to initial public offering arose initially from their fear of losing control of their family businesses. These family BGs became heavily indebted to state-owned banks, a common practice in Bangladesh (Rashid, 2013), often making the banks vulnerable to the BGs. As one CFO commented, "If our group fails, at least three banks will collapse." The BGs themselves remained private limited companies. Over time, they allowed some of their business units to be listed on the stock exchange, but kept the companies under family control (Rashid, 2013). According to the World Bank (2009), sponsors from the founders' families hold 43 per cent of the market, and 38 per cent is held by the public at large.

In addition to the historical capitalist legacy, the family elites were further empowered by political connections and social relations (Uddin et al., 2016; Sobhan, 1980). In the process of rapid growth, the BGs often leveraged the social capital of founder families to gain access to external resources, such as bank loans, business deal negotiations, regulatory lobbies, and so on. Previous research also finds a positive impact of BG affiliation on access to finances and other resources (see Masulis et al., 2011). As one CFO opined, "Whatever documents you provide, no bank would finance without personal guarantees from the sponsor directors. Their controlling interest will persist, whatever rules and regulations are made."

Personal guarantees for stock exchange limited companies are perhaps one of the key indicators of how creditors, and indeed other stakeholders, view the BG-affliated PLCs. Similarly, the family directors interviewed were notably empathetic with the role of family values, trust relations and commitment in contributing to the growth of the PLCs. This further 
amplifies family control interests in BG-affiliated PLCs, reflecting family directors' desire to retain full control over the enterprise.

\subsubsection{Relationships between family directors, shareholders and managers: family control}

The relative positions of three important stakeholders in family BGs - family directors, general shareholders and managers - provide insights into the power of dominant players. As clarified in Section 5.1.1, family directors enjoy structural advantages over other key players and are in a position to introduce family control into BG-affiliated PLCs. Typical conflicts of interest arising from separation of ownership and control are not prevalent in the family BGs, which operate through complex shareholding and ownership structures usually known as "pyramid" ownership structures (Morck et al., 2005). In order to retain control, driven by the family logics, the founders deliberately reserve the entire board and key management positions for their family and clan members (see World Bank, 2009). Entrenchment of family control within the BGs ultimately provides the family directors with unrestricted access to inside information and decision-making power.

Family involvement often blurs the separation of household and business. Our interviews with founder family directors gave us a glimpse into their family attachments to the business, such as grooming sons and daughters for future managerial roles. The family directors interviewed confirmed that inheritance, business interests and trust were always prioritised over professional capabilities, skills and competence in making board appointments. This is also reflected in the World Bank's $(2009$, p. 5) finding that the nomination process is "neither formal nor transparent". Now, third-generation family members are stepping into the BGs that we studied. The family governance literature contends that such desires for "socio-emotional wealth" magnify control and management entrenchment (Gómez-Mejía et al., 2011; Yoshikawa and Rasheed, 2010).

The main board functions, including service and monitoring, are in essence performed by the executive committee (EC). With no representations from general shareholders on ECs, the family directors usually dominate the EC process. This committee has become a proxy for each BG-affiliated PLC. "Active" family directors and "trusted" managers are placed in the EC to ensure that strategic information and decision-making power remain entrenched within the controlling family. Our access to confidential company byelaws and directors' codes of conduct allowed us to glean insights into the power entrusted to EC members over strategic and operational decision making and control. One family CEO with EC membership commented:

Board of Directors meeting is more of a formality. EC cannot legally approve, for example, a loan application. Only EC-approved recommendations and files are sent for legal board approval. In my group, EC meetings are held monthly, and being the president, I am the main decision maker.

Importantly, the same family member does not necessarily command EC positions in all listed PLCs held by a BG. One director, who held an EC position in a particular PLC within a group, commented: "I am looking after this one. I also sit in other boards [within the group] but I'm not involved in their ECs. My other family members are there." The corporate governance literature documents similar tactics used by corporate elites and families to intensify control and power, such as board dominance, family charters and codes of conduct (Siebels and $\mathrm{Zu}$ KnyphausenAufsess, 2012; Hermalin and Weisbach, 1998).

In this context, general shareholders (often the majority ownership of the company) find themselves in the position of "non-controlling owners". Their main material interests are therefore to make quick money in short-term trading, widely called "gambling" (Probe 
Committee, 1996). Allegedly, family directors often exploit the gambling tendencies of shareholders by artificially inflating or deflating share prices through trading within the group (see Probe Committee, 1996, 2011). One shareholder commented on his frustration:

Do you believe regulators would be able to hold their position if they took action against $X$ family? They [indicating family directors] are openly playing with rules and regulations.

Two recent stock market crashes in Bangladesh, in 1996 and 2010 respectively, seem to have benefited family directors at the expense of general shareholders (CPD, 2011). These events exemplify the vulnerability of the structural context, in which controlling interests may apparently inflict damage on non-controlling interests (Young et al., 2008).

From a CG perspective, the directors are responsible for monitoring managers to protect shareholders' interests. Thus, relationships between directors and managers are marked by inherent contradictions. However, such contradictions are not prevalent in the family BG settings, mainly owing to overlaps in ownership and management functions and relationships of trust. Instead, there are compatible internal relationships between family and non-family managers. Given the family elites' positions of power, (non-family) managers "accountable to families" emerge as the accepted norm. This was the sentiment of one young CFO: "I can guarantee you, no manager, whatever his professional background, can work without bothering the interests of higher-ups [family directors]. CEOs have enormous power." Given the powerful positions of family directors within the companies, non-family managers are prone to protect the family's interests at the expense of general shareholders in Bangladesh (CPD, 2011). Similar relationships between non-family managers and family directors are also reported in previous studies (Li and Filer, 2007).

\subsubsection{Relationships between donor agencies, state and regulators: emergence of CG guidelines}

In the early 1990s, international donor agencies put pressure on the Bangladeshi government to bring accountability and transparency into the public and private sectors (World Bank, 1993, 2002). This resulted in the formation of a new capital market regulatory body, the Bangladesh Securities and Exchange Commission (BSEC), in 1993. The change episode thus began in the wider structural domain, whereby the government mandated the BSEC to reform the local CG framework in line with Western best practice. There were intense reform pressures to enact a new Companies Act and a CG code mirroring the Anglo-American framework, change the listing rules, and create a professional oversight board (see ADB, 2003; World Bank, 2009).

The BSEC issued its first "comply or explain" CG code in 2006 for listed PLCs, mirroring the Anglo-American framework (BSEC, 2006). The relationship between regulatory bodies, such as the BSEC, and the Bangladeshi government requires some explanation. Although an autonomous body, the BSEC requires approval from the government to appoint its top executives. In other words, BSEC-like bodies are seen as part of the government machine. This clarifies why regulatory bodies such as the BSEC carry out the government's wishes.

Following the introduction of the comply or explain code in 2006, the World Bank, through its Reports on the Observance of Standards and Codes (ROSC) initiative, enacted "comprehensive webs of surveillance" to assess the state of CG in Bangladesh, benchmarking against OECD principles (World Bank, 2009; Soederberg, 2003, p. 9). ${ }^{6}$ Soon after the ROSC assessment, the BSEC proposed a mandatory CG code, namely the Bangladesh Corporate Governance Guideline, in 2012 (BSEC, 2012). As part of promoting their CG agenda, donor 
agencies continue to sponsor and organise various institutional reform projects, training, seminars and symposiums in association with civil society institutions (think tanks and professional bodies) and the media (BSEC, 2015; ADB, 2016). The new CG Guideline sought to institutionalise the CG principles or shareholder value logic espoused by the donor agencies. The next section details these reforms and discusses how key actors interacted with the new reforms.

\subsection{Social interaction at time T2}

The new CG Guideline triggered family BGs to foster accountability in their listed PLCs. Here, we focus on three main internal CG mechanisms seen as the main drivers of accountability to general shareholders: boards and committees, financial reporting, and internal control. The new CG Guideline provides limited coverage of external auditing, partly because it is seen as an external CG mechanism, and there have been separate legislatory and reform initiatives relating to external auditing practices in Bangladesh (The Financial Reporting Act, 2015; BSEC, 2014; World Bank, 2015, 2003). Since we were focusing mainly on regulatory changes imposed by the Guideline, interviewees were not invited to comment on external auditing practices.

The emergent properties or structural conditioning at $\mathrm{T} 1$, discussed earlier, provided us with some understanding of agential vested interests in both material and cultural spheres. In light of these, the next section discusses how actors (regulators, non-family managers, family directors and general shareholders) compromised, protected or resisted the CG reforms.

\subsubsection{Boards and committees}

International donors, such as the World Bank (2009, p. 4), had persistently raised concerns about the practice of concealing control by means of custodian accounts and holdings through related parties. Insiders (family directors) were seen "to benefit disproportionately" from such control. Curbing the power of ECs was hence the main thrust of the reform, including professionalisation and board independence. ${ }^{7}$

In terms of professionalisation, one reform was to create posts such as company secretary, AC chair, chief financial officer (CFO) and head of internal control to support board and committee operations. The requirement of the CG Guideline for the creation of additional posts was described as an "intervention of outsiders" and a "costly administrative burden". Consequently, most positions required by the Guideline were staffed through internal restructuring. Internal structural demands and the interests of dominant actors thus sustain EC practice surrounding the official board process.

The Guideline requires splitting of the $\mathrm{CEO}$ and chairman roles, inclusion of independent posts and committees, and qualification for various positions, with additional reporting and attestation requirements. Business groups prefer to reserve board chairmanship in affiliated PLCs for family members because, as one CEO said, "otherwise the outsider chairman will lack the sensitive and comprehensive business understanding essential to lead the group". Splitting the role of CEO and chairman makes little sense in substance when both are from the same family, often father and son. In this context, performance appraisal, monitoring of management and decision making take different dimensions. Family monitoring of management appears to work outside the board. Family BGs with representatives at different levels of management, long-term perspectives and greater access to inside information are in a unique position to monitor management effectively. This is consistent with Desender et al.'s (2013) contention that variations in the board monitoring function, which is not equally important in all firms, depend on ownership structure. 
In efforts toward regulatory compliance, ECs appear to be appointing professional CFOs and CEOs (in some cases) and independent directors. Nevertheless, closer investigation suggests that trusted individuals are strategically appointed to these new positions. The independent directors interviewed confirmed that their prior relationships with family directors had played a role in their getting board positions. Independent directors' résumés in annual reports suggest that some had or still have past and/or current managerial positions in other companies of the same BG. Thus, concerns that independence tests produce independence in appearance rather than reality are not unique to emerging economies (Carcello et al., 2011).

Even with trusted individuals on boards and committees, they are seen by EC members as ratifying bodies consisting of "outsiders". Family rhetoric, such as leakage of key strategic information and loss of competitiveness, renders group decision-making dynamics in the boardroom useless. One family director's comment was: "We don't want to compromise our competitiveness and comfort in reaching decisions for the sake of CG."

Independent directors interviewed affirmed that their "passive" role on the board and in committee meetings revolves mainly around signing documents or endorsing what the managers place before them. Some affiliated corporate boards, particularly those that are highly geared, have nominee directors from institutional investors. They also play a passive role, as reflected in a comment by a company secretary that "[t]hey only attend our board meetings". Independent and nominee directors are viewed as "outsiders" who have "nothing to lose". Previous research similarly documents the passive role of institutional investors. Yoshikawa and Rasheed (2010) report that Japanese banks seem sanguine about family control, as there is no evidence to suggest that they take an active interest in the CG of their family-run portfolio firms.

The control interests and confidentiality concerns of family directors are reflected in the practice of excluding outsiders from major corporate decisions. Family directors continue to control the board's agenda, information flow and decisions through their internal structural setup. Justifying the exclusion of independent directors, one family director opined, "The cost of genuinely sharing decision-making power with outsiders will be too high, not only for us but also for our shareholders." This interviewee was referring to leaking of confidential strategic and operational information to competitors.

\subsubsection{Internal control practice}

The internal management structures of BGs operate through the direct involvement of families. Their involvement in decision making, combined with various formal and informal communication channels, entails putting in place control structures that align realisation of company goals with family interests. Thus, the internal control structures of BGs provide a different dimension from the control mechanisms that traditionally operate through informal channels and processes. The following comment of a second-generation director appeared to undermine the need for a formal internal control function, despite this being required in the CG Guideline:

Even if I [finance director] approve a project, our CFO will not execute it without informing my father [Chairman] formally or informally. Due to such close supervision and monitoring, a separate department in a structured manner does not exist, truly speaking.

Reform measures such as the appointment of a head of internal control are tackled by restructuring existing positions. One head of internal control, who had been promoted from the position of finance manager, described his new responsibilities as follows: 
I would not say my job responsibilities have changed much. Secretarial responsibilities in audit committee and preparation of review reports on financial performance and internal policy compliance are added. Other responsibilities, like reviewing the accounting system, interim reporting to regulators, group accounting and application of accounting standards, reporting budget variances and carrying out special engagements as required by management (for example, loan approval, tender papers), remain the same.

The heads of internal control interviewed mentioned the emergence of informal, management-led internal control functions. One said: "As far as shareholders' [non-controlling owners'] rights are concerned, existing practice will not provide an additional cushion when the audit committee is not functional." The practice of reporting to the CEO (head of management), rather than the board or AC, seems to make it less likely that insider trading and related-party transactions will be flagged up. ${ }^{8}$ According to one CFO, "From time to time, our CEO at his discretion authorises specific personnel to conduct investigations into certain areas of the operation. Besides that, he has other internal sources of information."

The AC is also made dysfunctional by various measures, including appointing family members and trusted individuals, keeping the terms of reference vague and controlling information flows, as reflected in our interviews. The minutes of AC meetings indicate that board review and approval of quarterly and semi-yearly financial reports are the main concern of committee members: not a single case of recommendation, let alone refusal, was noted. Other substantial matters, including risk management, external audit and internal control, are never discussed at AC meetings, nor are the authorities and responsibilities attached to these areas defined in the terms of reference. The AC chairmen interviewed commented that their role is limited only to AC meetings, which "hardly ever takes more than 30 minutes". Disclosures of $\mathrm{AC}$ activities in annual reports never exceed the minimum regulatory requirement for four meetings. It seems that these meetings are deliberately kept standardised in terms of approving important papers. One family director, the company secretary sitting on the AC, who was also an EC member, commented:

Previously we could finalise papers on an ad hoc basis; now it's a lengthy process requiring AC approval, then board approval. Also, confidentiality issues are there due to the presence of outsiders.

The audit oversight mechanism required under the Guideline is made ineffective by fostering the EC's involvement in this respect. Similarly, company secretaries, CEOs and CFOs tend to balance their functions to reflect the families' priorities for confidentiality, trust and control. With a desire to protect each other's interests, practices remain stable, even in the face of overwhelming pressures from the regulatory bodies to change in favour of general shareholders.

\subsubsection{Financial reporting practice and accountability to general shareholders}

The integrity of financial reporting received some attention in the recent Guideline. A specialist $\mathrm{AC}$ consisting of an independent chair and at least two other members is required to exercise oversight over financial reporting and auditing in the interests of the general shareholders. In addition, the CEO and CFO are required to certify the integrity of reporting. Despite these efforts, as confirmed by CFO interviewees, only EC members have access to highly confidential accounts: "Banks here don't mind lending businesses based on 'in house' financials" (Rashid, 2013). One CFO linked this to the performance criteria for progress in the job: "The attitude of owners is that paying lucrative remuneration packages to chartered accountants is worth it for tax savings, smooth flow of finances, and regulatory compliance." 
This is consistent with the finding of previous studies that accounts departments often acquiesce with the wishes and decisions of high-ups (Uddin and Choudhury, 2008; Uddin, 2009). The BSEC, with its new CG Guideline, now requires a separate certification of CG compliance, which according to one BSEC official makes the monitoring process "more rigorous". Regulatory actors claimed that corporate transparency has improved during the post-reform era. Another BSEC official claimed:

At least they are getting acquainted with the culture of disclosing information, though some sort of concern on the quality of such disclosures remains. I would say it will take time and, compared to the past trend, companies are now more transparent.

Companies produce voluminous annual reports containing certified CG compliance reports, mission and vision statements, industry trend analyses, analyses of company performance, directors' résumés and shareholding status, actions of the AC, sustainability reports, and photographs demonstrating CSR. Our examination of their annual reports suggests that disclosures on issues sensitive to the rights of non-controlling shareholders (for example, director nominations, indirect shareholdings, related-party transactions, insider trading, and actions of ACs to enhance the integrity of audited financial reports) tend to be less extensive than the regulatory requirements.

Accountability of family directors and owners to general shareholders via annual reports remains a far cry, while accountability to general shareholders via AGMs is also compromised. The BSEC introduced reforms to the conduct of AGMs, including video recording of meetings, reporting to the regulator on proceedings, banning gifts, reports of CEOs and CFOs, the AC chair and auditors on CG guidelines to general shareholders, mandatory attendance of independent directors and auditors, and surprise visits by the regulator to AGMs. These heavy-handed measures suggest concerns about AGMs in Bangladesh (Uddin and Choudhury, 2008). Nevertheless, reforms have failed to have any significant impact, as family interests continue to dominate AGMs. Our observations of six of these meetings confirm that they are stage-managed by making them short and chaotic, often with the help of hired musclemen. Board nominations of directors and auditors and key decisions are passed by default. Using their position of power and control of boards, families render the AGM process symbolic.

Thus, families' aggressive pursuit of control interests pushes general shareholders to secure material gains from elsewhere. General shareholders continue to prioritise their material interests through short-term trading, rather than acting as organised pressure groups to change CG practices. In explaining the context of the 2011 share market turmoil, the CPD (2011) commented on an influx of investors eager to engage in short-term trading as if they were participating in a "Keynesian beauty contest". Shareholders involved in "share business" (which is how they define their investment in listed PLCs) exhibit acute reliance on speculation to satisfy their material interests.

Some regard shareholder activism as "value-less" or "matters beyond their control" in a context of weak enforcement of general laws and CG codes. Shareholders' trust in regulatory enforcement was severely shaken following two massive stock market upsets, as the culprits went unpunished (Probe Committee, 1996, 2011; Economist, 1996). A slow judiciary and political cronyism often complicate the pursuit of remedies in court (Uddin et al., 2016). Indeed, weak protection of general shareholders' rights is a common institutional feature in many emerging economies (Claessens and Fan, 2002; La Porta et al., 2000). 


\subsection{CG practices (structural elaboration) at time T3}

Theoretically, the outcome of agential interactions at time T2 is the material and cultural elaboration of CG practices at time T3. It is important to note that the structural context within which the previous social interactions took place involved four sets of interlinked structures: (i) relationships between positions (shareholders, managers and family directors) within the companies, (ii) relationships between the BGs and the BSEC, (iii) relationships between the state and donor agencies and the BSEC, and (iv) the dominance of family logics in BGs. It is clear that no changes occurred in any of the above structural conditioning. The following discussion elaborates on this.

With no substantial change in the wider economic and political structure, the state remains committed to the demands of donors (ADB, 2003). When the BSEC came up with a new CG Guideline imposing a shareholder value logic, the new structural pressures forced the BGs, traditionally governed through and dominated by a family logic, to protect the interests of general shareholders. Facing intense regulatory pressure to change CG practices, BGs started to comply with the CG Guideline (Sobhan, 2016). In the process of compliance, some "new" positions were created, including $\mathrm{CFO}$, independent director, head of internal audit, company secretary and AC. With no substantial change in the internal material and cultural set-up, previous practices continued relatively changed and with largely symbolic compliance. Actors holding positions at the firm level retained their previous ideas, interests and internal structures. Managers continued to act in the interests of the dominant corporate actors. Actors coming into the "new" positions tended to conform to the internal structural and cultural conditions: some deliberately ignored the external structural pressures prioritising personal relationships, while others could not act effectively against the internal set-up that marshalled resources.

The changing CG rules and regulations, which created incentives or pressures for these actors to act in the best interests of general shareholders, did not seem to alter the apparently simple but complex internal structural set-ups. Thus, regulatory efforts to institutionalise a shareholder value logic (in order to empower general shareholders) failed to circumvent the power of family directors. Theoretically, the imposed CG ideas might have succeeded through a material change in the control and power dynamics of family BGs. However, since the control and power dynamics of family BGs within and beyond the organisation remained intact, CG practices remained stable, even though the regulatory framework changed.

\section{Discussion}

This paper aims to elaborate a political economy of the change and stability of CG practices to assist in explaining why certain CG reforms fail in one context but work in others. The morphogenetic approach provides a meta-theoretical (methodological) guideline to develop a suitable theory, or what Archer $(1995$, p. 328) calls 'practical social theory' (PST), of social change and stability. Following this approach, our inquiry centres around the underlying material and cultural conditions necessary to sustain certain types of CG practice, and how actors enabled and/or constrained by those conditions ultimately shape CG practices. In answering these questions, drawing on the morphogenetic approach, we provide a three-stage, practical, socialtheoretical model of CG change and stability, as depicted in Figure 2.

\section{[Insert Figure 2]}


Figure 2 summarises the findings of this paper. The difference between Figures 1 and 2 is a distinction between the theoretical or expected and the practical or actual model of CG change and stability. As Figure 2 shows, we identify four major outcomes, or structural elaborations, of change efforts (at T3): adoption of a shareholder value-based, Anglo-American CG framework; no change in structural conditioning (relations between positions and institutions); symbolic compliance with the Anglo-American framework to maintain positions and relationships; and shareholders continuing to produce an aggregate effect on the reproduction of CG practices. These resultant practices can be traced back to T1.

The morphogenetic approach guides us to look into structural conditioning (material and cultural conditions). Figure 1 illustrates the structural conditions, and how they dispose actors to change the system or preserve the status quo. At T1, the first step is to identify material and cultural conditioning such as relations between positions, institutions and ideas. Thus, we identify the key material and cultural conditions, the extent of their interdependence (internal or contingent relationships) and logical linkages (compatible or contradictory), as presented in Figure 2. These are: contingently compatible relations between the state and donor agencies; internal compatible relations between the state and regulators; internal contradictory relations between regulators and BGs; internal compatible relations between family directors and managers; internal contradictory relations between general shareholders and family directors; and contingent contradictory relations between family logics and general shareholder value.

Material and cultural conditions tend to create specific situational logics of action for actors. Archer (1995) identifies four distinct situational logics of actors: protection, compromise, opportunism and elimination (see Figure 1). Actors consider situational logics in the context of their material advantages, cultural conditions and life projects. To understand this, the morphogenetic approach guides us to examine social interactions at T2. Archer (1995) argues that actors' social interactions take place through a process of mediation and reflection, during which the generative power of structural conditioning impinges on actors, and actors reflect on the situation subjectively.

Drawing on our empirical data and the aforementioned situational logics, we find six key socio-interactions and actions (see Figure 2). These are: the logic of opportunism for the state in the context of contingently compatible relations between donor agencies and the state; the logic of protection for regulators in the context of internal compatible relations between the regulators and the state; the logic of compromise for both regulators and BGs in the context of internal contradictory relations between the two groups; the logic of protection for managers in the context of internal compatible relations between family directors and managers; the logic of compromise for general shareholders in the context of internal contradictory relations between general shareholders; and the logic of elimination for family directors in the context of contingent contradictory relations between family logics and general shareholders. These are discussed below.

First, opportunism by the Bangladeshi state and donor agencies resulted in acceptance of Western ideas of CG. Contingently compatible relations between the state and donor agencies meant that agential actions would be opportunistic. Access to resources provided by the donor agencies led the government to adopt the framework prescribed, as did many other emerging economies. The Bangladeshi state could have brushed off these interventions as it had contingent relationships with the international agencies. However, external economic dependence and widening state access to resources led the government to adopt a strategy of opportunism and accept the prescriptions. 
Second, regulators played a role in protecting the state's interests in the CG reform measures. Direct and indirect government control over the BSEC exemplifies Archer's configuration of compatible internal relationships. This strategy of protection by the BSEC also influenced how it dealt with contradictory relationships with family directors.

Third, cultural antagonism and the compromise of family directors and regulators resulted in symbolic compliance and lax regulations. Symbolic compliance can be better understood if we look at relationships between the BGs and the regulators, which are relationships of "necessity" but are contradictory. They take a systematic strategic stance of compromise to avoid clashing with any potential regulatory intervention that might affect the continuity they seek. Our analysis also suggests that the actors systematically avoided regulatory measures, largely by making them dysfunctional in various ways, ${ }^{9}$ as well as through superficial compliance and mobilisation as a powerful group to make their voices heard through formal channels. ${ }^{10}$ At the same time, the regulatory institutions were embroiled in a situational logic of protection with the state. As a result of their strategy of protecting their own and the state's interests, actors holding positions in regulatory institutions sought to compromise with the BGs. Taking advantage of such compromises, family elites were able to gain some concessions, such as lax regulatory oversight of AGMs.

Fourth, non-family managers and incumbents in new positions found themselves protecting the interests of dominant corporate actors (i.e. family). As Figure 2 demonstrates, the relation between the two positions is internally compatible. Protecting family interests is in the material interests of managers. They appear to owe their jobs to the families, and are hence reluctant to act in contradiction with family interests, out of a sense of loyalty and/or fear. Managers in BGs tend to have long tenure and informal and flexible KPIs, and often receive preferential treatment from their founder. One family director described their practice of "grooming individuals to fill critical management positions" as a "continuous process". Ties with the founder's region of origin are prevalent among employees of the three BGs. In this way, the unofficial norm of family loyalty has become deeply internalised in BGs.

Fifth, the new CG Guideline crystallised the structured contradiction between the two owner groups: families and dispersed shareholders. Shareholders had a structural predisposition to become a locus of opposition to the prevailing structures. However, given the internal relationships and the aggressive pursuit of vested interests by the family directors, the shareholders had to adopt a strategy of compromise and maintain the status quo, continuing to engage with short-term selling rather than widespread shareholder activism, and thus serving their own material interests. Dispersed shareholders, with their limited shared experience and scope, did not permit the emergence of a collective identity, and since general shareholders had limited access to resources compared with families, they had no other choice but to seek compromises with family owner groups.

Last but not least, the contradictory relationship between family and shareholder value logics meant that family directors were able to continue to uphold the family's control interests at the expense of shareholders' wealth maximisation. Family directors were more likely to adopt a strategy of elimination because of the contingent nature of the two logics. In Archer's terms, family directors are corporate actors, an organised group of actors, with common vested interests and power, who remain united in pursuit of their interests. In a changing regulatory context, the family directors faced pressure to change their CG practices. However, their material and cultural interests, associated with the position of controlling owner, contradicted the regulatory pressures of empowering shareholders. For instance, board independence did not satisfy the 
cultural interests of the families. With deep-seated concern for family control, they had strong incentives to perpetuate their empowering internal material and cultural set-up.

The actors' social interactions reveal that they adopted strategies demanded by the situational logic, as suggested by Archer (1995); but they did not blindly follow this logic. They subjectively interpreted and weighed the influences and decided on their courses of action in light of their prioritised concerns and life projects. Hence, family directors could not entirely ignore the regulatory influences, but managed to keep the internal structure and culture largely unaltered, with symbolic compliance but no significant change in practice. This also explains why non-family managers facilitated family controls and shareholders remained passive. According to the morphogenetic approach, the ultimate outcome or structural elaboration of social interactions at T3 leads to morphogenesis (change) or morphostasis (no change). In our case, the CG reforms did not change the internal structural set-ups of the BGs. Efforts to circumvent the power of family directors and the institution of a shareholder value logic did not materalise. Thus, $C G$ practices remained largely unchanged.

Illustrating CG practices in the shape of a morphogenetic cycle of structural conditioning $\rightarrow$ social interaction $\rightarrow$ structural elaboration enabled us to develop a practical social theoretical model of CG change and stability (see Figure 2). In the process, we gained some insights into why certain CG reforms fail in one context but work in others. We also acknowledge some challenges of applying a meta-theoretical guideline such as the morphogenetic approach, in the social science field in general and the CG field in particular. First, while the morphogenetic approach provides general guidelines and freedom for researchers to develop a specific theory in their field, it lacks specificity and boundaries. It requires us to look for material and cultural conditioning and agents' reflections, with few theoretical concepts to guide us. In our case, our understanding of the CG literature enabled us to find key material and cultural conditioning in the CG field. For instance, our identification of the importance of regulators, the state and family directors was derived from previous studies. Second, understanding agential reactions (social interactions) was a key stage in determining why and what changed or remained stable. While such an approach enables us to identify situational logics, it does not guide us on how to attach those situational logics to key actors. Finally, agential reflections of structural conditioning are assumed to be similar at individual and collective levels. Deconstructing deeper individual reflections would have provided us with better insights, for instance into why some agents, such as family directors or managers, may give preference to their cultural interests over material interests.

\section{Conclusions}

This paper has provided an account of why CG reforms have failed to generate the expected change in CG practices in BGs in Bangladesh. Based on our analysis of interviews with family directors, independent directors, managers, regulators and shareholders of three large BGs, combined with documentary evidence and observation, our paper unpacks organisational CG practices. Inspired by the morphogenetic approach, we have examined structural conditioning and social interactions to understand the outcomes of reforms. We have identified some key structural conditioning that shapes social interactions and, in turn, CG practices. The role of donor agencies and the state was important in pushing through Anglo-American-inspired CG reforms in Bangladeshi companies dominated by family BGs. The new CG Guideline sought to institutionalise the shareholder value logic and enhance accountability to general shareholders by strengthening boards and committees, internal controls and the integrity of financial reporting. 
We find that cultural conditioning, such as the dominance of family logics, is a key factor in PLCs, partly arising out of the historical capitalist legacy, political connections and social relations. These, in turn, shape relations between the positions of family directors, general shareholders and managers, and give rise to family control in BGs.

We have also identified some social interactions shaped by the aforementioned structural conditioning which, in turn, determined the outcomes of CG reforms. Strategies of elimination, compromise, opportunism and protection were adopted by regulators, family directors, managers and general shareholders, depending on the situation. For instance, managers adopted a protection strategy and continued to act in the interests of the dominant family directors. The new regulatory pressures forced the BGs to comply with the CG Guideline. In response, family directors, adopting a strategy of compromise, created new positions to keep the regulators at bay, and kept internal structures and culture largely unaltered, with no significant change in practice.

This paper makes several contributions. First, considerable attention has been devoted to variations in CG practices across different institutional and organisational settings (Aguilera and Crespí-Cladera, 2016). However, we argue that such analyses have struggled to capture deeper underlying institutional conditions and their mediations through agency, both theoretically and empirically, neglecting the political economy of CG practice and change. According to critical realist scholars, in studies of organisational practices, including $C G$, these underlying conditions require due emphasis from separate material, cultural and agential ontological positions (Mutch, 2017; Herepath, 2014). This leads us to focus on the importance of being specific about the material, cultural and agential properties of CG practices. We have developed a three-stage, practical, social-theoretical model of $\mathrm{CG}$ change and stability to provide a more nuanced explanation of CG reform, practices and change. This is illustrated (see Figure 2) through an exploration of $\mathrm{CG}$ change initiatives within the empirical site of BGs, showing a need for clarity between the material and cultural conditions and agential reception of particular forms of CG change.

Second, the paper also informs ongoing debate by providing evidence that variations in CG practices across different institutional and organisational contexts cannot be understood with reference to economically rational agential actions, behavioural modelling and contractual relationships. Actors may use multiple interpretive schemes, depending on their interests, concerns and life projects. The paper sheds light on the subjective meanings that actors attach to the objective situations they face. For instance, both the material and cultural interests of the family directors made them less receptive to regulatory demands for change, and neither the general shareholders nor the regulators appeared to ward off efforts by the existing power holders, the families.

Third, in the face of ongoing recession and integration of markets around the world, the challenges of CG reforms, practices and change will continue unabated in the field of CG, at least in the near future. CG research has to some extent failed to engage with this challenge, despite its fundamental importance, especially owing to its orientation toward studying CG practices as a "black box". Our paper offers a morphogenetic explanation of CG practices in the Bangladeshi family BG setting, using them as an illustrative example to elaborate the methodological possibilities of critical realism for empirical CG research (O'Mahoney and Vincent, 2014).

While accounting institutional studies rely predominantly on a macro perspective to describe how CG reforms trigger distinct challenges (see Yonekura et al., 2012), we adopt a political economic perspective that does not downplay agential concerns, subjectivities and lived 
experiences. Our findings suggest that macro-level policy reforms have little impact on microlevel CG practices. These findings warrant a search for an alternative perspective to the way CG is understood in the existing accounting literature. CG is not simply a set of technical mechanisms to solve typical agency problems by creating incentives for agents. It is a social phenomenon that emerges from the actions and interactions of agents within a complex set of forces, including external economic forces and related ideologies, national economic conditions, state policies, company ownership structure, and so on.

We have responded to Gendron's (2009, p. 130) call to pay attention to "the potential of qualitative research in developing a variety of grounded and innovative understandings about corporate governance in action" by balancing methodological rigour and epistemological openness in conducting accounting research. The methodological framework offered in this paper underpins epistemological openness by going "beyond the agency-institutional continuum in order to study corporate governance in action" (ibid, p. 128) and is beneficial to the literature because it provides theoretical space to acknowledge and incorporate how prevailing (material and cultural) structures enable the choices and actions of key agents to constrain changes in practice amid stakeholder pressures for change. Therefore, we believe that this paper will stir new reflections and debate, and incite interest in the area of realist social theory, which has reportedly remained marginalised in the interdisciplinary field of $C G$ research to date.

We now turn to consider some important implications for future research and policy makers. First, the paper opens space for further research, especially by applying a metatheoretical guideline such as the morphogenetic approach for more nuanced explanations and a more inclusive understanding of CG practices, reform and change in different organisational and institutional settings. In particular, it would be useful to examine CG reforms and change in cross-cultural contexts to gain a better understanding of why some reforms fail in one context but appear to work well in others. The context of family BGs in Bangladesh may share many similarities with other emerging and poorer economies, such as a lack of well-developed democratic institutions, the dominance of families, and poverty and corruption. Nevertheless, differences between emerging and poorer countries are equally notable, such as stages of development, historical and colonial legacies and cultural orientations. More importantly, the morphogenetic approach used here could be replicated in other countries to generate new insights into rationales for change and stability in the CG field, given the differences and similarities noted above.

Second, our findings highlight the relevance of further research into how structural and cultural contexts affect the subjectivity of powerful agents (for example, institutional investors, political elites) alongside agential evaluation of the applicability and relevance of imposed CG reforms. The presence of multiple powerful actors with divergent interests would complicate the process further. In such contexts, further investigation of how actors choose and act strategically in processes of restraining institutional change might provide a better understanding of the dynamics of practice developments in a CG field with multiple, and often conflicting, logics. Divergent expectations of stakeholders may condition conflict, paradoxes and politics in debates about $\mathrm{CG}$ reform, practice and change.

Third, Archer has extended the morphogenetic approach by incorporating agential reflexivity and subjectivities mediating structural influences (Archer, 2003). This extension may open up innovative avenues for understanding the motivations, behaviour and strategies of agential adoption of and resistance to imposed rules and regulations. This approach might also be used in more specific areas of the CG field, such as AC practices. 
Finally, the positive social impact of this research is not just "academic" in nature. The morphogenetic approach would be an effective tool to enable policy makers to see their reforms in action. By recognising and articulating the generative power of material culture and agency, it provides deeper explanations of why, for instance, family directors either resist or accept proposed CG reforms. Often, when regulators find family directors resisting a CG change, they attribute it to the directors' vested material interests. This paper allows policy makers to understand that the reasons for resisting changes may reside in the cultural realm. Identifying these cultural conditions, such as family value logics, will provide policy makers, including donor agencies and the state, with a better handle on the situation, thus increasing their chances of implementing CG reforms and improving practices.

\section{References}

ADB (2003), "Capacity Building of the Securities and Exchange Commission and Selected Capital Market Institution", The Philippines: Asian Development Bank.

ADB (2016), "Capital Market Development in Bangladesh: A Sector Reform Perspective", Philippines: Asian Development Bank.

Aguilera, R.V. and Crespí-Cladera, R. (2012), "Firm family firms: current debates in corporate governance in family firms", Journal of Family Business Strategy, Vol. 3 No. 2, pp. 6669.

Aguilera, R.V. and Crespí-Cladera, R. (2016), "Global corporate governance: on the relevance of firms' ownership structure”, Journal of World Business, Vol. 51 No. 1, pp. 50-57.

Ahrens, T., Filatotchev, I. and Thomsen, S. (2011), "The research frontier in corporate governance", Journal of Management \& Governance, Vol. 15 No. 3, pp. 311-325.

Ahrens, T. and Khalifa, R. (2013), "Researching the lived experience of corporate governance", Qualitative Research in Accounting \& Management, Vol. 10 No. 1, pp. 4-30.

Archer M.S. (1995), Realist Social Theory: The Morphogenetic Approach, Cambridge University Press, Cambridge.

Archer, M.S. (2003), Structure, Agency and the Internal Conversation: The Morphogenetic Approach, Cambridge University Press, Cambridge.

Archer M.S. (2013), Social Morphogenesis and the Prospects of Morphogenic Society. In: Archer M. (eds) Social Morphogenesis. Springer, Dordrecht.

Beasley, M. S., Carcello, J. V., Hermanson, D. R. and Terry, L. N. (2009), “The audit committee oversight process", Contemporary Accounting Research, Vol. 26 No. 1, pp. 65-122.

Bettinelli, C. (2011), "Boards of Directors in Family Firms: An Exploratory Study • of Structure and Group Process", Family Business Review, Vol. 24 No. 2, pp. 151-169.

Brennan, N.M., and Solomon, J. (2008), “Corporate governance, accountability and mechanisms of accountability: an overview", Accounting, Auditing \& Accountability Journal, Vol. 21 No. 7, pp. 885-906.

Brennan, N.M., Kirwan, C.E. and Redmond, J. (2016), "Accountability Processes in Boardrooms: A Conceptual Model of Manager-Non-Executive Director Information 
Asymmetry", Accounting, Auditing \& Accountability Journal, Vol. 29 No. 1, pp. 135164.

Brennan, N.M. and Kirwan, C.E. (2015), "Audit Committees: Practices, Practitioners and Praxis of Governance", Accounting, Auditing \& Accountability Journal, Vol. 28 No. 4, pp. 466493.

BSEC (2006), Corporate Governance Guidelines. Notification No. SEC/CMRRCD/2006158/Admin/02-08 of 20 February 2006, Dhaka: Bangladesh Securities and Exchange Commission.

BSEC (2012), Corporate Governance Guidelines. Notification No. SEC/CMRRCD/2006158/134/Admin/44 of 07 August 2012, Dhaka: Bangladesh Securities and Exchange Commission.

BSEC (2014), Guidelines for Conducting Special Audit of Companies. Amendments to the Securities and Exchange Rules 1987, Notification No. SEC/CMRRCD/200180/158/Admin/12. Dhaka: Bangladesh Securities and Exchange Commission.

BSEC (2015), BSEC Annual Report, Dhaka: Bangladesh Securities and Exchange Commission.

Carcello, J., Neal, T., Palmrose, Z. and Scholz, S. (2011), "CEO involvement in selecting board members, audit committee effectiveness, and restatements", Contemporary Accounting Research, Vol. 28 No. 2, pp. 396-430.

Claessens, S., and Fan, J. P. H. (2002), "Corporate governance in Asia: A survey", International Review of Finance, Vol. 3 No. 3, pp. 71-103.

Colli, A. and Colpan, A.M. (2016), "Business groups and corporate governance: review, synthesis, and extension", Corporate Governance: An International Review, Vol. 24 No. 3, pp. 274-302.

Cohen, A. D., Dey, A. and Lys, T. Z. (2013), "Corporate Governance Reform and Executive Incentives: Implications for Investments and Risk Taking", Contemporary Accounting Research, Vol. 0, No. 0, pp. 1-39.

CPD (2011), Independent Review of Bangladesh's Development, Centre for Policy Dialogue, Dhaka, Bangladesh, available at: http://www.cpd.org.bd/downloads/IRBD\% 20FY11_First\%20Reading.pdf (accessed 28 July 2012).

Christopher, J. (2010), "Corporate governance: A multi-theoretical approach of recognizing the wider influencing forces impacting on organisations", Critical Perspectives on Accounting, Vol. 21 No. 8, pp. 683-695.

Cullen, M.M. and Brennan, N.M. (2017), "Differentiating Control, Monitoring and Oversight: Influence of Power Relations on Boards of Directors - Insights from Investment Fund Boards", Accounting, Auditing \& Accountability Journal, Vol. 30 No. 8, pp. 1867-1894.

Cuomo, F., Mallin, C. and Zattoni, A. (2016), "Corporate governance codes: a review and research agenda", Corporate Governance: An International Review, Vol. 24 No. 3, pp. $222-241$. 
Desender, K.A., Aguilera, R.V., Crespi, R. and Garcia-Cestona, M. (2013), "When does ownership matter? Board characteristics and behavior", Strategic Management Journal, Vol. 34 No. 7, pp. 823-842.

Economist (1996), "The Bangladesh stock market: slaughter of the innocents", The Economist, 7 December, pp. 7-13.

Galhofer, S., and Haslam, J. (2017), "Some reflections on the construct of emancipatory accounting: Shifting meaning and the possibilities of a new pragmatism", Critical Perspectives on Accounting. doi:10.1016/j.cpa.2017.01.004

Gendron, Y. (2009), "Discussion of "The audit committee oversight process", Contemporary Accounting Research, Vol. 26 No. 1, pp. 123-134.

Gendron, Y., and Be'dard, J. (2006), "On the constitution of audit committee effectiveness", Accounting, Organisations and Society, Vol. 31 No. 3, pp. 211-39.

Gómez-Mejía, L.R., Cruz, C., Berrone, P. and De Castro, J. (2011), "The bind that ties: socioemotional wealth preservation in family firms", The Academy of Management Annals, Vol. 5 No. 1, pp. 653-707.

Guthrie, J. and Parker, L.D. (2012), "Reflections and projections: 25 years of interdisciplinary perspectives on accounting, auditing and accountability research", Accounting, Auditing \& Accountability Journal, Vol. 25 No. 1, pp. 6-26.

Hermanson, D. R., Tompkins, J. G., Veliyath, R., and Ye, Z. (2012), "The compensation committee process", Contemporary Accounting Research, Vol. 29 No. 3, pp. 666-709.

Herepath, A. (2014), "In the loop: a realist approach to structure and agency in the practice of strategy", Organisation Studies, Vol. 35 No. 6, pp. 857-879.

Hermalin, B.E. and Weisbach, M.S. (1998), "Endogenously chosen boards of directors and their monitoring of the CEO", American Economic Review, Vol. 88 No. 1, pp. 96-118.

Holderness C.G. (2009), "The myth of diffuse ownership in the United States", Review of Financial Studies, Vol. 22 No. 4, pp. 1377-1408.

Jalal, A. (1990) The State of Martial Rule: The Origins of Pakistan's Political Economy of Defence. Cambridge: Cambridge University Press.

Jansson, A. and Larsson-Olaison, U. (2015), "I heard it through the grapevine: market control of controlling family shareholders", Corporate Governance: An International Review, Vol. 23 No. 6, pp. 504-518.

Jansson, A. and Larsson-Olaison, U., Veldman, J. and Beverungen, A. (2016), "Editorial: The political economy of corporate governance", Ephemera: Theory and Politics in Organisation, Vol. 16 No. 1, pp. 1-17.

Joseph, J., Ocasio, W. and McDonnell, M.-H. (2014), "The structural elaboration of board independence: executive power, institutional logics, and the adoption of CEO-only board structures in US corporate governance", Academy of Management Journal, Vol. 57 No. 6, pp. 1834-1858.

Khan, M. (1999), “The Political Economy of Industrial Policy in Pakistan 1947-1971”, Working Paper, Department of Economics, SOAS, University of London. 
Kochanek, S.A. (1996), "The rise of interest politics in Bangladesh”, Asian Survey, Vol. 36 No. 7, pp. 704-722.

La Porta, R., Lopez-De-Silanes, F., Shleifer, A. and Vishny, R. (2000), "Investor protection and corporate governance", Journal of Financial Economics, Vol. 58 No. 1-2, pp. 3-27.

La Porta, R., Lopez-de-Silanes, F. and Shleifer, A. (1999), "Corporate ownership around the world", The Journal of Finance, Vol. 54 No. 2, pp. 471-518.

Li, S. and Filer, L. (2007), "The effects of the governance environment on the choice of investment mode and the strategic implications", Journal of World Business, Vol. 42 No. 1, pp. 80-98.

Lien, T., Teng, C., and Li, S. (2015), "Institutional Reforms and the Effects of Family Control on Corporate Governance", Family Business Review, Vol. 1 No. 1, pp. 1-15.

Malsch, B., Tremblay, M-S and Gendron, Y. (2012), "Sense-Making in Compensation Committees: A Cultural Theory Perspective", Organisation Studies, Vol. 33 No. 3, pp. $389-421$.

Marnet, O. (2007), "History repeats itself: the failure of rational choice models in corporate governance", Critical Perspectives on Accounting, Vol. 18 No. 2, pp. 191-210.

Masulis, R.W., Pham, P.K. and Zein, J. (2011), "Family business groups around the world: financing advantages, control motivations, and organisational choices", Review of Financial Studies, Vol. 24 No. 11, pp. 3556-3600.

McNulty, T., Zattoni, A. and Douglas, T. (2013), "Developing corporate governance research through qualitative methods: a review of previous studies", Corporate Governance: An International Review, Vol. 21 No. 2, pp. 183-198.

Merino, B.D., Mayper, A.G., and Tolleson, T.D. (2010), "Neoliberalism, deregulation and Sarbanes-Oxley", Accounting, Auditing \& Accountability Journal, Vol. 23 No. 6, pp. 774-792.

Mihret, D. G. (2014), "How can we explain internal auditing? The inadequacy of agency theory and a labor process alternative", Critical Perspectives on Accounting, Vol. 25 No.8, pp. 771- 782 .

Mihret, D. G. and Grant, B. (2017), "The role of internal auditing in corporate governance: a Foucauldian analysis", Accounting, Auditing \& Accountability Journal, Vol. 30 No. 3, pp. 699-719.

Morck, R., Wolfenzon, D. and Yeung, B. (2005), "Corporate governance, economic entrenchment, and growth", Journal of Economic Literature, Vol. 43 No. 3, pp. 655-720.

Muttakin, M.B, Monem, R.M., Khan, A. and Sunramaniam, N. (2015), "Family firms, firm performance and political connections: Evidence from Bangladesh", Journal of Contemporary Accounting and Economics, Vol. 11 No. 3, pp. 215-230.

Mutch, A. (2017), "Margaret Archer and a morphogenetic take on strategy", Critical Perspectives on Accounting. doi:10.1016/j.cpa.2016.06.007

Mutch, A. (2007), "Reflexivity and the institutional entrepreneur: a historical exploration", Organisation Studies, Vol. 28 No. 7, pp. 1123-1140. 
Nicholson, G., Pugliese, A. and Bezemer, Pieter-Jan. (2017)," Habitual accountability routines in the boardroom: How boards balance control and collaboration ", Accounting, Auditing \& Accountability Journal, Vol. 30 Iss 2 pp. online first.

O'Mahoney, J., and Vincent, S. (2014), Critical realism as an empirical project: a beginner's guide. In P. Edwards, J. O'Mahoney, \& S. Vincent (Eds.), Putting Critical Realism into Practice: A Guide to Research Methods in Organisation Studies. London: Oxford University Press.

Parker, L.D. (2008), “Interpreting interpretive accounting research”, Critical Perspectives on Accounting, Vol. 19 No. 6, pp. 909-914.

Parker, L. D. and Northcott, D. (2016), "Qualitative generalising in accounting research: concepts and strategies", Accounting, Auditing \& Accountability Journal, Vol. 29 No. 6, pp. $1100-1131$.

Papanek, G. F. (1967) Pakistan's Development, Social Goals and Private Incentives, Cambridge Mass: Harvard University Press.

Papanek, H. (1972), "Pakistan's big businessmen: Muslim separatism, entrepreneurship and partial modernization”, Economic Development and Cultural Change, Vol. 21 No. 1, pp. $1-32$.

Peng, M.W. and Jiang, Y. (2010), "Institutions behind family ownership and control in large firms", Journal of Management Studies, Vol. 47 No. 2, pp. 253-273.

Pesqueux, Y. (2005), "Corporate governance and accounting systems: a critical perspective", Critical Perspectives on Accounting, Vol. 16 No 6, pp. 797-823.

Probe Committee (1996), Investigation Report of Probe Committee, Probe Committee, Dhaka, Bangladesh.

Probe Committee (2011), Investigation Report of Probe Committee, Probe Committee, Dhaka, Bangladesh.

Rashid, M. (2013), "Family-owned businesses in Bangladesh", The Financial Express (Bangladesh), 29 January, available at: http://print.thefinancialexpressbd.com/old/index.php?ref=MjBfMDFfMjlfMTNfMV8yXzE1ODQyMg== (accessed 12 June 2015).

Rose, J.M., Mazza, C. R., Norman, C.S. and Rose, A. M. (2013), "The influence of director stock ownership and board discussion transparency on financial reporting quality", Accounting, Organisations and Society, Vol. 38 No. 5, pp. 397-405

Sayer, R.A. (1992), Method in Social Science: A Realist Approach, 2nd ed., Taylor \& Francis, London.

Seal, W. (2006), "Management accounting and corporate governance: An institutional interpretation of the agency problem", Management Accounting Research, Vol. 17 No. 4, pp. 389-408.

Schulze, W.S., Lubatin, M.H. and Dino, R.N. (2003), "Exploring the agency consequences of ownership dispersion among inside directions in family firms", Academy of Management Journal, Vol. 46 No. 2, pp. 179-194. 
Shaoul, J., Stafford, A. and Stapleton, P. (2012), "Accountability and corporate governance of public private partnerships", Critical Perspectives on Accounting, Vol. 23 No. 3, pp. 213 229.

Soederberg, S. (2003), “The promotion of 'Anglo-American' corporate governance in the south: Who benefits from the new international standard", Third World Quarterly, Vol. 24 No. 1, pp. 7-27.

Siddiqui, J. (2010), "Development of corporate governance regulations: the case of an emerging economy”, Journal of Business Ethics, Vol. 91 No. 2, pp. 253-274.

Siebels, J.-F. and $\mathrm{Zu}$ Knyphausen-Aufsess, D. (2012), "A review of theory in family business research: the implications for corporate governance", International Journal of Management Reviews, Vol. 14 No. 3, pp. 280-304.

Sikka, P. and Stittle, J. (2017), "Debunking the myth of shareholder ownership of companies: Some implications for corporate governance and financial reporting", Critical Perspectives on Accounting. doi:10.1016/j.cpa.2017.03.011

Sobhan, A. (2016), "Where Institutional Logics of Corporate Governance Collide: Overstatement of Compliance in a Developing Country, Bangladesh", Corporate Governance: An International Review, Vol. 24 No.6, pp. $599-618$.

Sobhan, R. (1980), "Growth and contradiction within the Bangladeshi bourgeoisie", Journal of Social Studies, Vol. 1 No. 9, pp. 1-27.

Sobhan, R. (2002), The Political Economy of the State and Market in Bangladesh, Centre for Policy Dialogue, Dhaka, Bangladesh.

Solaiman, S.M. (2006), "Recent reforms and development in the securities market of Bangladesh", Journal of Asian and African Studies, Vol. 41 No. 3, pp. 195-228.

Stein, M.J. (2008), "Beyond the boardroom: governmental perspectives on corporate governance", Accounting, Auditing \& Accountability Journal, Vol. 21 No. 7, pp. 10011025.

Subramaniam, N., Stewart, J., Ng, C. and Shulman, A. (2013), "Understanding corporate governance in the Australian public sector A social capital approach", Accounting, Auditing \& Accountability Journal, Vol. 26 No. 6, pp. 946 - 977.

The Financial Reporting Act (2015), (Act No. XVI of 2015). Published in the Bangladesh Gazette Extraordinary dated 09 September 2015. Dhaka: Bangladesh Government Press.

Tremblay, M.S. and Gendron, Y. (2011), "Governance prescriptions under trial: On the interplay between the logics of resistance and compliance in audit committees", Critical Perspectives on Accounting, Vol. 22 No. 3, pp. 259-272.

Turley, S. and Zaman, M. (2007), "Audit committee effectiveness", Accounting, Auditing \& Accountability Journal, Vol. 20 No. 5, pp. 765-788.

Uddin, S.N. (2009), "Rationalities, domination and accounting control: a case study from a traditional society", Critical Perspectives on Accounting, Vol. 20 No. 6, pp. 782-794. 
Uddin, S. and Choudhury, J. (2008), "Rationality, traditionalism and the state of corporate governance mechanisms", Accounting, Auditing \& Accountability Journal, Vol. 21 No. 7, pp. 1026-1051.

Uddin, S., Siddiqui, J. and Islam, M.A. (2016), "Corporate social responsibility disclosures, traditionalism and politics: a story from a traditional setting", Journal of Business Ethics. doi:10.1007/s10551-016-3214-7.

Westphal, J.D. and Graebner, M.E. (2010), "A matter of appearances: how corporate leaders manage the impressions of financial analysts about the conduct of their boards", Academy of Management Journal, Vol. 53 No. 1, pp. 15-44.

World Bank (2015), Bangladesh: Report on the Observance of Standards and Codes (ROSC)Accounting and Auditing. Washington, DC: World Bank.

World Bank (2009), Bangladesh: Corporate Governance Country Assessment - Report on the Observance of Standards and Codes (ROSC), Washington, DC: World Bank.

World Bank (2003), Bangladesh: Report on the Observance of Standards and Codes (ROSC)Accounting and Auditing. Washington, DC: World Bank.

World Bank (2002), Bangladesh: Financial Accountability for Good Governance. Washington, D.C.: World Bank.

World Bank (1993), Bangladesh: Implementing Structural Reforms. Washington, D.C.: World Bank.

Yonekura, A., Gallhofer, S. and Haslam, J. (2012), "Accounting disclosure, corporate governance and the battle for markets: The case of trade negotiations between Japan and the U.S.”, Critical Perspectives on Accounting, Vol. 23 No 4-5, pp. 312-331.

Yoshikawa, T. and Rasheed, A.A. (2010), "Family control and ownership monitoring in familycontrolled firms in Japan”, Journal of Management Studies, Vol. 47, pp. 274-295.

Young, M.N., Peng, M., Ahlstrom, D., Bruton, G.D. and Jiang, Y. (2008), "Corporate governance in emerging economies: a review of the principal-principal perspective", Journal of Management Studies, Vol. 45 No. 1, pp. 196-220.

\footnotetext{
Notes

${ }^{1}$ The Foucauldian notion of governmentality in explicating internal auditing as a disciplinary mechanism of CG (Mihret and Grant, 2017); institutional theory to understand the isomorphic pressures and institutionalisation of the Anglo-American CG framework (Yonekura et al., 2012; Siddiqui, 2010): an institutional account of agency to overcome the limitations of economic agency (Seal, 2006); Weber's notion of traditionalism to elucidate the tension between traditional and rational models of CG (Uddin and Choudhury, 2008); Latour's conception of trials of strength to explain key actors' resistance to imposed CG regulations (Tremblay and Gendron, 2011); labour process theory to explorate the emergence of internal audits (Mihret, 2014); cultural theory to make sense of compensation committee processes (Malsch et al., 2012); and a social capital approach to understand public-sector CG (Subramaniam et al., 2013).

2 "Structural conditioning" is defined as the way material and cultural relationships shape the social contexts or situations in which agents operate.

${ }^{3}$ A life project is defined as a constellation of agential concerns. Actors prioritise their concerns while defining
} 
their ultimate "concern" and accommodating others reflexively. In realising their concerns, humans, by virtue of their nature, act strategically.

${ }^{4}$ The Framework tool summarises voluminous and messy raw data according to key themes. This process started with indexing, involving the application of categories to the data. Once indexed, the data sources (e.g., interview comments) were then sorted and synthesised under key categories or themes. This was followed by the production of a thematic chart, which contained synthesised and summarised data in a matrix-based form.

${ }^{5}$ Most family owners outside the EC remain largely inactive.

${ }^{6}$ Soederberg (2003) refers to the World Bank's country assessment under the ROSC initiative as a web of surveillance. Under the ROSC initiative, the World Bank encourages poorer countries to develop a country action plan mirroring the Anglo-American framework.

7 "Professionalisation" in the new code indicates that companies must appoint experienced and qualified people into newly-created positions to deliver best CG practice.

${ }^{8}$ Allegations of insider trading and related-party transactions are traditionally common in Bangladesh (World Bank, 2009). The BSEC has recently imposed strict provisions against insider transactions (e.g. mandatory disclosure of sales of shares by sponsors) and greater limitations on potential conflicts of interest (e.g. prohibiting loans from company funds to directors and executives).

${ }^{9}$ For example, the practice of completely detaching the board (open to outsiders) from strategic decision making within the PLCs by relying on the EC structure.

${ }^{10}$ The Bangladesh Association of PLCs (BAPLC), a lobby group representing PLCs in Bangladesh, is de facto an association of family owners. 


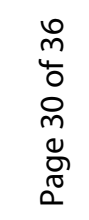

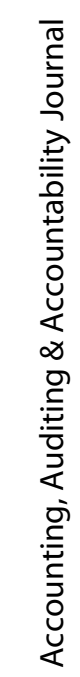

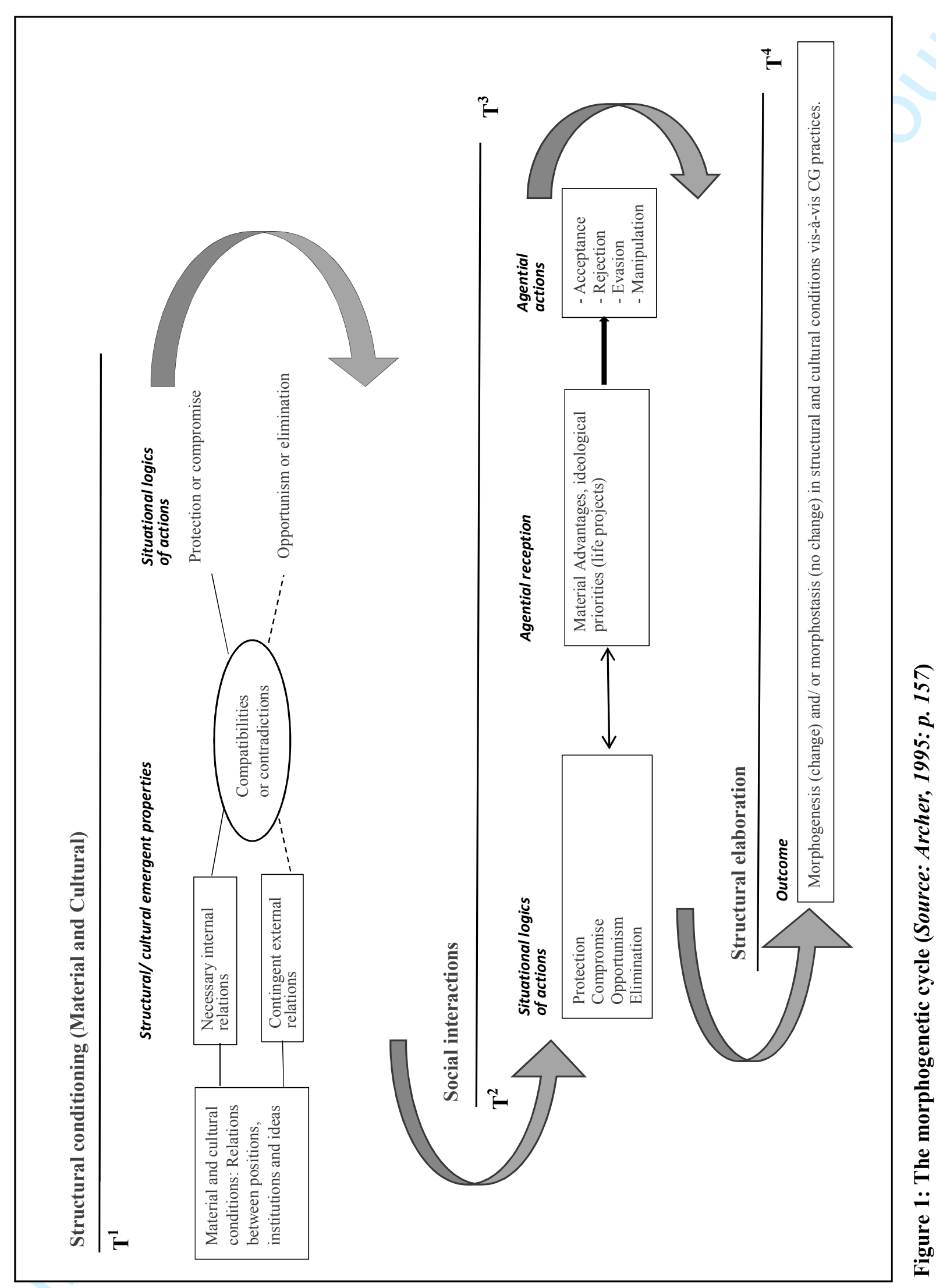

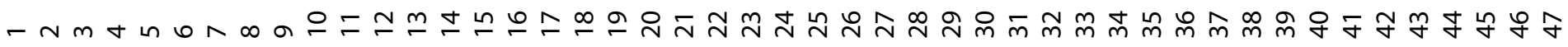




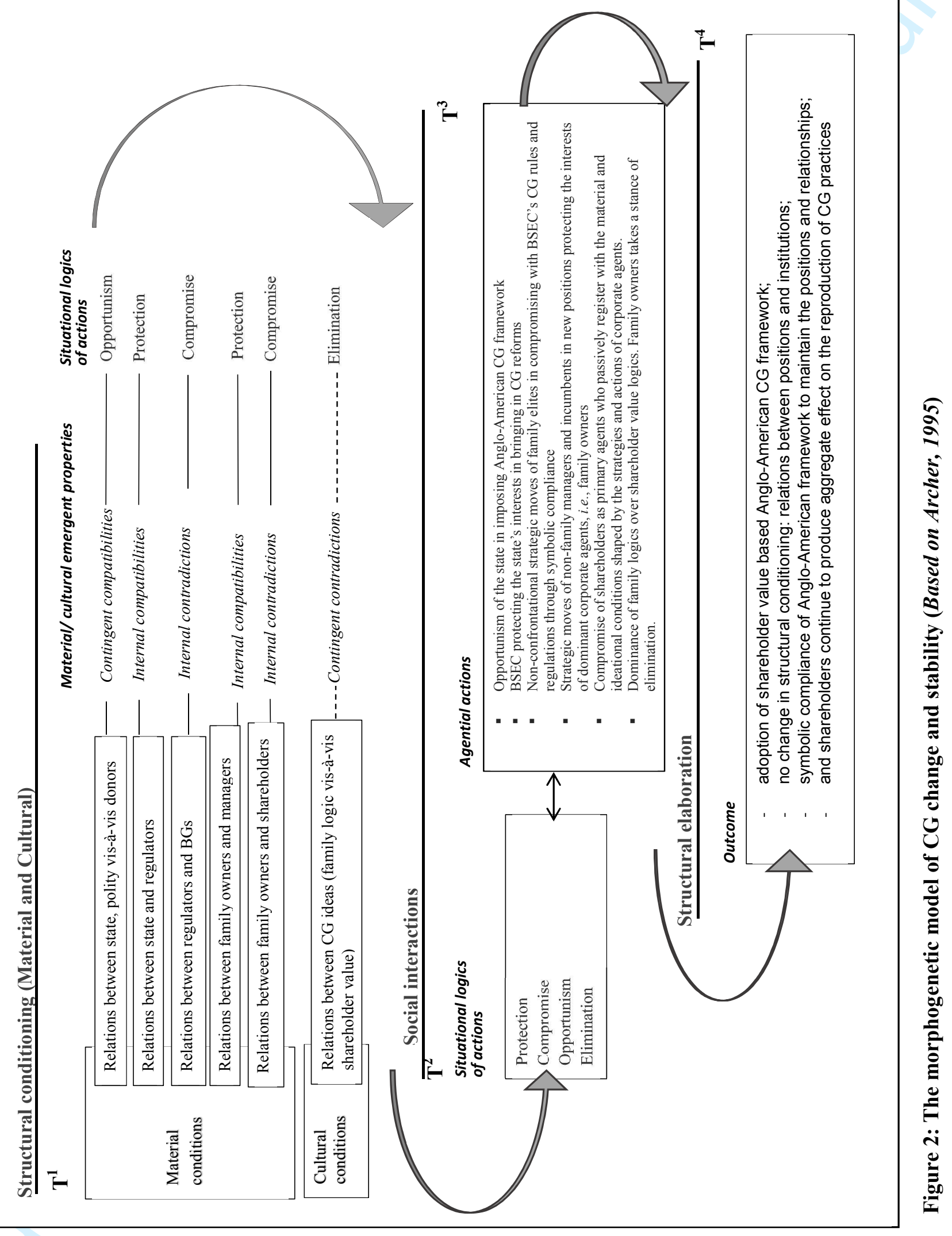

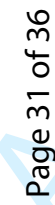


Toward a Political Economy of Corporate Governance Change and Stability in Family Business Groups: A Morphogenetic Approach

Ref: AAAJ-01-2017-2833.R1

The revised paper has been enhanced in the revision process. Further improvement is to be made, both in dealing with some of the previously provided comments and some other suggestions for amendment. Some comments raised on first round review have yet to be adequately dealt with in the revised paper.

Response: We wish to thank the reviewer for the constructive comments. This has been really helpful for us. We believe, the paper is now much clearer especially in terms of its theoretical framework, contributions and implications for future research opportunities and policy. Overall, the whole paper has improved substantially. We would not be able to do it without the reviewer's feedback.

The first of these relates to the explanation of Archer's "three strata - material, cultural and agential". The explanation remains insufficiently unclear. In revising this material, consider defining some terms used such as "structural conditioning" and "structural elaboration".

Response: Thanks. We have revised the section again. Provided some examples for clarifications (see p. 5). We do acknowledge the section was a difficult read. Given the space and also flow of arguments, we have made another attempt to make it clearer. Hopefully it is much better reading now.

Second, the treatment of the "external audit' feedback in an endnote (no. 12) appears to downplay the importance of the initial inquiry. The note itself is also not convincing. While the statement is made that "External Audit was not the main source of the reform in the CG guidelines in question", a following sentence makes the point "The BSEC CG Guidelines concern oversight of the integrity of financial reporting through [the] audit committee". It seems that "external audit" was not overlooked or downplayed by these guidelines, even thought it "was not the main source of the reform", but that it was not ignored either. In other words, the endnote is not convincing. More particularly, why was "external audit" not the concern of the author(s)? An adequate explanation within the within the text of the paper would be appreciated.

Response: Thank you for your comments and giving us the opportunity to clarify for not focusing on external auditing. We have inserted some narratives in the paper (please see p. 12), reference and an endnote (8) to explain as to why we did not focus on external audit. It was partly because there have been separate legislations and reforms by BSEC concerning external auditing in Bangladesh. The coverage for external auditing in the CG guideline is as far as the audit committee's activities in relation to the integrity of financial reporting.

The paper keeps its focus only on the guideline partly because, we thought, the external auditing indeed need focused discussions in relation to auditing and accounting standards, the role of accountancy firms and auditors and the impact of reforms and legislations on external auditing practices. Since the focus of our paper is mainly the Guideline imposed regulatory changes, 
interviewees were not invited to comment on external auditing practices.

Third, in referring to the two rounds of interviews, which were conducted over three years apart, outline specifically whether the second round of interviews were required to obtain different data not gathered before and why this occurred or why "more data" was required to be generated. What different or additional date was sought in the second round and why was this necessary? A fuller explanation is warranted in view of the time difference and the vagueness of the response to the earlier feedback provided.

Response: Again many thanks. We have now made it clearer why the second round was needed in the research method section. See page 7, last para.

Fourth, the query about the "key research question" in the paper has not been adequately deal with in the revised paper. While it is stated as being "Yes, it is an empirical issue ...", it is now timely to specifically state whether this is the key research question being addressed in this study?

Response: Apologies for misunderstanding of your comment. We have now revised the text and provided sign posting to make it clear to the reader the key research question of the paper (last few sentences of para 2 and first sentence of para 3 )

The discussion section of the paper requires some further development in terms of the better integration or application of Archer's framework. What has this study contributed to "the theory" in terms of the usage and the identified limitations or weaknesses of this framework in the context of this investigation?

Response: Thank you. The discussion section is now fully revised in order to demonstrate how we develop a political economy of the change and stability of CG practices, inspired by metatheoretical guidelines such as morphogenetic approach. We have also reflected on our evidence and the theoretical guidelines adopted in the paper in terms of limitations or weaknesses. Our reflections are now inserted in the last part of the discussion section (Please see page 16-19).

The conclusion of the paper would benefit from some further development. The first sentence stated as "This paper makes several contributions." is not a promising start. It would be preferable begin with a more macro-perspective to outline the main orientation of the paper and summarise what has been provided in terms of key findings and interpretations. The several contributions would preferably follow this overview.

Response: The conclusion section is now fully revised. Key findings are summarised in page 19-20 as you suggested.

After detailing the key contributions, it is recommended to pose and answer the "So what" question in a convincing fashion.

Response: Thanks for this, we believe the revised conclusion section reflects the points emphasized for the revision. Particularly, the discussion in pp. 21-22 attempts to answer the "So what" question.

The statement "We believe this will stir new reflections and debate, and incite interest in the areas of 'realist' theory that has reportedly remained marginalised in the interdisciplinary field of CG 
research to date". Apart from necessarily supporting the "reportedly remained marginalised" point, it is recommended to try to make more substantive remarks on further research opportunities or agenda or policy and other implications that may arise, especially in the international context.

Response: Thanks. We have made substantial revisions to the section to reflect the points made above. Addressed in page 21-22.

\section{Other suggestions}

These minor suggestions are presented in point form as follows:

- In different places throughout the paper, the word "the" is missing, such as in the abstract (Findings - "the expected results"), page 5, line 33 ("the morphogenetic approach"), page 12 , lines $34 / 35$ with related suggestions ("The independent directors interviewed provided advice that confirmed their prior relations ...") and page 25, line 43 (Endnote 12 - "the audit committee"). (Addressed)

- At different places in the paper, long statements by interviewees are included but not intended even though they exceed 30 or so words. For example, page 10, lines 22-26 and page 13 , lines $29-36$. The sentence on page 16 spanning lines $35-44$ is too long and needs to be split into 2-3 sentences. (Addressed)

- The Abstract contains the same sentence under "Research implications" which appears in the bottom of page 18 in the "Conclusion". This is not seen as sufficiently original in terms of convincing portrayal of the implications of the study, apart from the concerns expressed above about this statement. (Addressed)

- On page 2, line 15, consider replacing "engaged with" with "examined" so as to state "Some studies have examined CG practices ...". (Addressed, please see p. 2)

- At the end of page 2, the statement "We aim to fill this gap" appears in respect to the "Second" of two reasons. For the "First" reason, however, do the author(s) have a similar purpose or intention? If so, that should be stated at the end of the sentence finishing on line 49. (Addressed)

- On page 3 , line 19, why state "Perhaps this is lucidly pointed out in Pesqueux ..." (emphasis added). It is either pointed out or not pointed out in such terms? Perhaps also (oddly) appears on the same page at line 38. (Addressed, please see p. 3)

- On page 3 , line 44 "this debate" is stated, but the nature of this debate should be made clearer. (Addressed, please see p. 3)

- On what page in Ahrens and Khalifa (2013) or McNulty et al, 2013) does "Micro-myopia" appear?

Response: "Micro-myopia" is not coined by either McNulty et al. (2013) or Ahrens and Khalifa (2013) rather this is our reflection based on the literature.

- On page 4, line 3, consider replacing "its" with "the" so as to state "... in terms of the coverage ...". (Addressed, please see p. 4)

- On the same page, are there any more recent references available to cite than Bettinelli, 2011 and Li and Filer, 2007? 
Response: These two references are relevant although not very recent.

- Also on page 4, line 34, consider replacing "unpacks" with "unpack". (Addressed)

- Endnote 2 (page 4, line 54) should be positioned in Section 4 of the paper. (Addressed, please see p. 8)

- On page 5 , line 42, on what page of Archer (1995) is "meta-theoretical guideline" first stated or defined? In general, add page numbers where terms are being drawn from other authors. (Addressed, please see p. 5)

- On page 5 , line 57 , "These conditioning" is not clear. Consider clarifying by stating "conditioning factors" or conditioning ingredients" or similar. (Stated as "conditioning influences')

- On page 6 , line 18 , stating "in light of their life projects" seems to be narrow or limiting. Clarification is desirable to make the intended meaning clear.

- On page 6, line 21, consider adding "made available for this investigation" after “..., and unpublished internal documents". (Addressed, please see p. 7)

- On page 8 , line 28 , consider adding the sentence "These are each addressed in turn as follows;" after "...: donor agencies and the state". (Addressed, please see p. 8)

- On page 9 , line 26 from top, it is seems desirable to add further (earlier published) references when only "Uddin et al, in press" is the only available item to be found [at least to the knowledge of the author(s)]. [Added Sobhan (1980), please see p. 9]

- On page 9 , line 46 , insert "are" before "in a position to introduce ...". (Addressed, please see p. 10)

- On page 10 , line 5 , what are meant by "cum directors"? [we really meant family directors (directors who are also the owners, now changed it to family directors)] On the same page, line 44, consider inserting "respectively" after "... in 1996 and 2010". (Addressed, please see p. 11)

- On page 11 , line 15 , adds relevant references to support this statement, finishing with "... into the public and private sectors". On the same page, explain what is meant in stating "comprehensive web of surveillance". (Addressed, please see p. 12)

- On page 12, "professionalisation" is suddenly introduced but with no introduction or definition. Is appears to be unwarranted but, if seem to be necessary, an appreciation of the sudden need to use this term should be provided to readers.

Response: The point on 'professionalization' introduced here is linked to the last line of the previous paragraph. Also 'professionalization' is defined in the endnote.

- On page 13 , line 48 , consider replacing "individual" with "individuals" so as to state "... and trusted individuals". (Addressed, please see p. 13)

- On page 14, line 3, consider adding "that" after "seems" so as to state "It seems that these meetings ...". (Addressed, please see p. 14)

- On page 15, line 35 , it is stated "The following elaborate this". The question is posed: "What is 'the following"'? (Addressed, please see p. 16)

- On page 16 , line 50 , consider replacing "fail" with "failed" so as to state "... into being and failed ...". (This line is revised in the process of reorganising the discussion section)

- On page 17 , line 51 , aim to clarify what is intended in stating "contingently contradictory relationship". Also on page 17 last line of page, consider replacing "But" with "However" so as to state "However, their material and ...". (Addressed, please see p. 19)

- On page 18 , line 8 (new paragraph) consider stating instead "The actors in most cases, therefore, adopted strategies ...". (This line is revised in the process of reorganising the discussion section) 
Hopefully, the feedback above (some of which has been necessarily repeated) is helpful in the further development and refinement of this work. 